\title{
Produksi enzimatis Virgin Coconut Oil (VCO) dengan enzim bromelin serta pemurniannya menggunakan adsorben zeolit
}

\author{
Septiany Palilingan ${ }^{* a}$, Meity Pungus ${ }^{b}$ \\ a Kimia, FMIPA, Universitas Negeri Manado, Tondano, 95618, Indonesia \\ ${ }^{b}$ IKM, FIK, Universitas Negeri Manado, Tondano, 95618, Indonesia
}

INFO ARTIKEL

Diterima 16 Oktober 2018

Disetujui 30 Oktober 2018

\section{Key word:}

Bromelain

Extract of pineapple stem

VCO

\section{Kata kunci:}

Bromelin

Ekstrak batang buah nanas VCO

${ }^{*}$ e-mail:

septianypalilingan@unima.ac.id

*Telp:

085256407756

\begin{abstract}
A BSTRACT
One of the processed coconut products that is beneficial to health and has been widely used as an industrial raw material is VCO. Traditional rural communities and households have produced their own VCO for personal consumption because of its health benefits. However, the production process of VCO which still traditionally produces VCO products with a standard of quality and yield that has not been maximized. The research was carried out by enzymatic method, which added the enzyme bromelain contained in pineapple stem extract into coconut milk. The VCO product obtained was then purified by zeolite adsorbent, and water content and free fatty acid levels were tested. The results showed the highest VCO yield was found at a concentration of $20 \%$, which was $36 \%$ and the purification of VCO with adsorbent zeolite was proven to reduce water content and free fatty acid levels with the highest percentage decrease in water content by $66 \%$, and the highest percentage decrease in free fatty acid $63 \%$. From the results of the study it can be concluded that the addition of pineapple stem extract containing the enzyme bromelain in the production of VCO can increase the yield of VCO to a maximum of $35.9 \%$ and purification of VCO samples with adsorbent zeolite proven to help reduce water content and free fatty acid levels.
\end{abstract}

\section{A BSTRAK}

Salah satu produk olahan buah kelapa yang bermanfaat bagi kesehatan dan telah banyak dijadikan sebagai bahan baku industri adalah VCO. Masyarakat tradisional pedesaan dan rumah tangga telah memproduksi sendiri VCO untuk konsumsi pribadi karena khasiatnya bagi kesehatan. Akan tetapi proses produksi VCO yang masih tradisional menghasilkan produk VCO dengan standar kualitas dan rendemen yang belum maksimal. Penelitian dilakukan dengan metode enzimatis, yaitu menambahkan enzim bromelain yang terkandung dalam ekstrak batang buah nanas ke dalam santan kelapa. Produk VCO yang diperoleh selanjutnya dimurnikan dengan adsorben zeolit, dan dilakukan pengujian kadar air dan kadar asam lemak bebas. Hasil penelitian menunjukkan rendemen VCO tertinggi terdapat pada konsentrasi $20 \%$, yaitu sebesar $36 \%$ serta pemurnian VCO dengan adsorben zeolit terbukti dapat menurunkan kadar air dan kadar asam lemak bebas dengan persentasi penurunan kadar air tertinggi sebesar $66 \%$, dan persentasi penurunan kadar asam lemak bebas tertinggi sebesar 63\%. Dari hasil penelitian dapat disimpulkan bahwa penambahan ekstrak batang buah nanas yang mengandung enzim bromelain dalam produksi VCO dapat meningkatkan rendemen VCO maksimal sebesar 35,9 \% dan pemurnian sampel VCO dengan adsorben zeolit terbukti dapat membantu menurunkan kadar air dan kadar asam lemak bebas. 


\section{Pendahuluan}

Salah satu jenis kekayaan hayati di Propinsi Sulawesi Utara Indonesia yang telah dimanfaatkan untuk kebutuhan masyarakat adalah buah kelapa. Buah kelapa telah lama dimanfaatkan masyarakat sebagai sumber makanan, obat-obatan maupun di bidang industri.

Salah satu produk olahan dari buah kelapa yang berkhasiat bagi kesehatan adalah Virgin Coconut Oil atau yang dilebih dikenal dengan istilah VCO. Secara ilmiah khasiat VCO bagi kesehatan antara lain mengurangi resiko penyakit kardiovaskular [1], antidiabetes dan antioksidan [2], mencegah penuaan dini dan menyembuhkan luka [3], dan masih banyak khasiat lainnya.

Masyarakat di pedesaan terutama industri rumah tangga telah memproduksi VCO sendiri secara tradisional. Akan tetapi produksi VCO dengan metode tradisional seperti ini dapat menghasilkan produk VCO dengan standar kualitas dan rendemen yang belum maksimal. Salah satu parameter kualitas produk VCO yang dapat digunakan adalah dengan menguji kadar air dan kadar asam lemak bebas. Adanya kandungan air dan asam lemak bebas yang berlebihan dapat mempercepat proses ketengikan pada produk VCO. Oleh karena itu, diperlukan suatu metode dalam produksi VCO yang dapat menghasilkan produk VCO dengan rendemen yang lebih banyak dan dapat menurunkan kandungan air dan asam lemak bebas dalam produk VCO. Salah satu metode yang dapat dilakukan adalah dengan melakukan produksi enzimatis, yaitu dengan menambahkan enzim bromelin pada santan kelapa, sehingga enzim ini akan menghidrolisis protein dan membuat minyak dapat terpisah dengan air dalam emulsi santan secara maksimal.

Enzim bromelin yang diperlukan dalam produksi VCO terkandung dalam tanaman nanas (Ananas comosus). Bromelin merupakan enzim protease yang mengkatalisis reaksi hidrolisis ikatan peptida dari protein [4]. Bromelin terdapat pada ekstrak daging buah atau batang buah nanas. Pemanfaatan tanaman nanas di masyarakat umumnya lebih pada daging buahnya saja, sedangkan bagian batang, bonggol dan kulit hanya dibuang sebagai limbah, padahal bagian batang juga mengandung bromelin yang dapat dimanfaatkan [5]. Dalam proses pemanenan nanas, setelah buah nanas dipetik, batang buah nanas hanya dibakar dalam keadaan masih tertanam sebelum pucuk-pucuk baru ditanam lalu dibuang [6]. Padahal batang buah nanas mengandung enzim bromelin yang dapat dimanfaatkan dalam berbagai kebutuhan seperti dalam produksi VCO.

Berdasarkan informasi tersebut telah dilakukan penelitian tentang produksi VCO dengan metode enzimatis, yaitu metode fermentasi dengan menambahkan ekstrak batang buah nanas yang mengandung enzim bromelin ke dalam santan kelapa. Pada proses enzimatis ini, bromelin yang terkandung dalam ekstrak batang buah nanas akan memecah lapisan protein pada emulsi santan sehingga minyak dapat terpisah sempurna dengan air. VCO yang dihasilkan, selanjutnya dimurnikan dengan menggunakan adsorben zeolit. Pemilihan adsorben zeolit ini, karena zeolit merupakan salah satu adsorben yang terbukti dapat memurnikan minyak, bahkan pada minyak jelantah [7]. Produksi VCO secara enzimatis dengan penambahan ekstrak batang buah nanas yang dilanjutkan dengan pemurnian dengan adsorben zeolit ini diharapkan dapat menghasilkan VCO dengan rendemen maksimal dan dapat menurunkan kandungan air dan asam lemak bebas dalam produk VCO.

\section{Bahan dan Metode}

Bahan-bahan yang digunakan adalah buah kelapa tua yang segar (berumur \pm 12 bulan), batang dari buah nanas mengkal, adsorben zeolit, glass wool, kertas saring, larutan etanol $96 \%$, larutan natrium hidroksida 0,05 $\mathrm{M}$, indikator $\mathrm{pH}$ fenolftalein, dan akuades. Alatalat yang digunakan antara lain sentrifuge, neraca analitik, oven, desikator, kolom kromatografi, hot plate stirrer, termometer, dan alat-alat gelas laboratorium.

\section{Penentuan konsentrasi ekstrak batang buah nanas optimum untuk produk VCO}

Sebelum dilakukan experimen, disiapkan terlebih dahulu krim santan kelapa dan ekstrak 
batang buah nanas yang akan digunakan. Selanjutnya dicampurkan ekstrak batang buah nanas ke dalam wadah berisi krim santan kelapa dengan perbandingan volume sesuai dengan tabel berikut :

Tabel 1. Perbandingan volume krim santan dan ekstrak batang buah nanas pada beberapa konsentrasi berbeda

\begin{tabular}{cccc}
\hline $\begin{array}{c}\text { Ekstrak } \\
\text { batang } \\
\text { buah } \\
\text { nanas } \\
(\%)\end{array}$ & $\begin{array}{c}\text { Kolume (mL) } \\
\text { Krim }\end{array}$ & $\begin{array}{c}\text { Ekstrak } \\
\text { batang } \\
\text { buah } \\
\text { Santan }\end{array}$ & $\begin{array}{c}\text { Total } \\
\text { volume } \\
(\mathbf{m L})\end{array}$ \\
\hline 0 & 500 & 0 & 500 \\
10 & 450 & 50 & 500 \\
20 & 400 & 100 & 500 \\
30 & 350 & 150 & 500 \\
40 & 300 & 200 & 500 \\
50 & 250 & 250 & 500 \\
\hline
\end{tabular}

Campuran didiamkan selama 10 jam sampai terbentuk 3 lapisan, minyak, blondo dan air. Minyak dipisahkan dengan menggunakan sentrifuge pada kecepatan 3000 rpm selama 10 menit. VCO yang diperoleh ditimbang rendemennya (gram) dan dihitung rendemen hasil (\%).

\section{Pemurnian VCO}

VCO disaring dengan menggunakan adsorben zeolit dalam kolom kromatografi (panjang $45 \mathrm{~cm}$, diameter $3 \mathrm{~cm}$ ) dengan tinggi adsorben $30 \mathrm{~cm}$. Sampel VCO dialirkan tetes demi tetes dengan kecepatan alir 1 tetes/detik dan ditampung dalam labu Erlenmeyer, selanjutnya sampel VCO dianalisis kadar air dan asam lemak bebasnya (Analisis kadar air dan asam lemak bebas dilakukan sesuai dengan prosedur [8].

\section{Analisis Statistika}

Semua eksperimen dilakukan 2 kali pengulangan dan data yang diperoleh diolah menggunakan software MS Excel dan SPSS.

\section{Hasil dan Pembahasan \\ Rendemen VCO}

Perbandingan rendemen VCO kontrol (0\%) (tanpa penambahan ekstrak batang buah nanas) dengan rendemen VCO optimum (20\%) (dengan penambahan ekstrak batang buah nanas yang mengandung enzim bromelin) dapat dilihat pada Gambar 1.

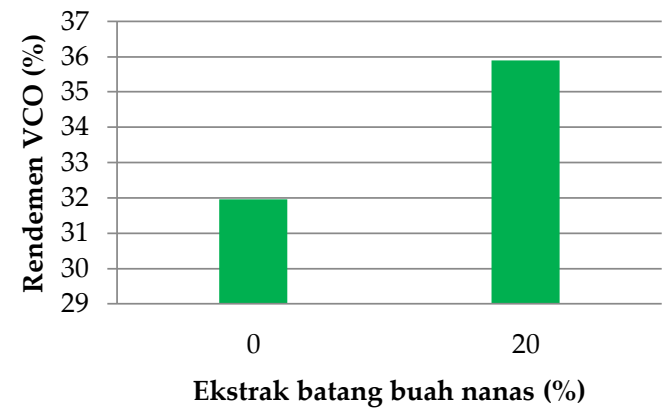

Gambar 1. Perbandingan rendemen VCO kontrol dengan rendemen VCO optimum

Dari data yang ditunjukkan pada Gambar 1 dapat dilihat bahwa penambahan ekstrak batang buah nanas yang mengandung enzim bromelin pada santan kelapa saat proses fermentasi, dapat menghasilkan rendemen VCO yang lebih tinggi (35.90\%) daripada rendemen VCO kontrol (31.96\%). Hal ini disebabkan karena enzim bromelin yang terkandung dalam ekstrak batang buah nanas dapat menghidrolisis protein dalam santan kelapa selama proses fermentasi yang terbukti dapat lebih memaksimalkan pemisahan minyak dengan air dalam emulsi santan sehingga rendemen VCO yang dihasilkan lebih tinggi dari pada kontrol. Pada percobaan ini didapatkan nilai konsentrasi ekstrak batang buah nanas yang optimum menghasilkan rendemen tertinggi pada konsentrasi $20 \%$.

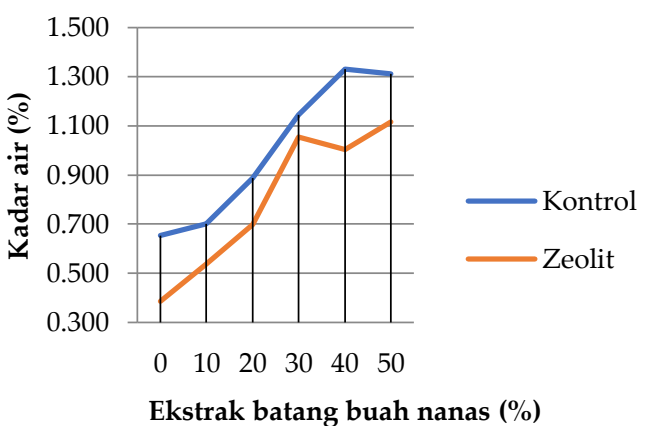

Gambar 2. Perbandingan kadar air VCO kontrol (tanpa pemurnian dengan adsorben zeolit) dengan kadar air VCO (melalui pemurnian dengan adsorben zeolit) 


\section{Kadar air}

Perbandingan data kadar air VCO kontrol (tanpa pemurnian dengan adsorben zeolit) dengan data kadar air VCO (melalui pemurnian dengan adsorben zeolit) disajikan pada Gambar 2.

Dari data pada Gambar 2, dapat dilihat bahwa VCO kontrol memiliki nilai kadar air yang lebih tinggi daripada VCO yang melalui pemurnian dengan adsorben zeolit. Dengan adanya perlakuan pemurnian VCO dengan disaring menggunakan asdorben zeolit terbukti dapat menurunkan kadar air VCO secara signifikan. Adanya penyaringan VCO dengan menggunakan adsorben zeolit terbukti berhasil menjerap sejumlah air, sehingga kadar air dalam produk VCO berkurang secara signifikan dan kualitas VCO menjadi lebih baik. Hasil analisis uji beda rerata dengan BNT (Tabel 2) pun menunjukkan bahwa terdapat signifikansi perbedaan rerata kadar air menurut adsorben. Rerata yang berbeda secara signifikan terlihat dari nilai peluang $\mathrm{p}<0,05$, dimana antara kontrol dengan adsorben zeolit, semuanya memenuhi nilai peluang $\mathrm{p}<0,05$. Hal ini menunjukkan bahwa secara uji statistika terdapat perbedaan yang signifikan untuk perlakuan pemurnian dengan adsorben dan kontrol terhadap kadar air dalam VCO.

Tabel 2. Hasil uji beda rerata dengan BNT pada perlakuan pemurnian dengan adsorben terhadap kadar air

\begin{tabular}{|c|c|c|c|c|}
\hline (I) & Adsorben & $\begin{array}{c}(\mathrm{J}) \\
\text { Adsorben } \\
\end{array}$ & $\begin{array}{l}\text { Perbedaan } \\
\text { rerata (I-J) }\end{array}$ & $\begin{array}{l}\text { Signifikansi } \\
\text { (p) }\end{array}$ \\
\hline & $\begin{array}{c}\text { Tanpa } \\
\text { pemurnian } \\
\text { (Kontrol) }\end{array}$ & $\begin{array}{c}\text { Adsorben } \\
\text { zeolit }\end{array}$ & 0.206 & 0.000 \\
\hline
\end{tabular}

Kadar asam lemak bebas (Free fatty acid, FFA)

Perbandingan data kadar asam lemak bebas VCO kontrol (tanpa pemurnian dengan adsorben zeolit) dengan data kadar asam lemak bebas VCO (melalui pemurnian dengan adsorben zeolit) disajikan pada Gambar 3.

Dari data pada Gambar 3, dapat dilihat bahwa VCO kontrol memiliki nilai kadar asam lemak bebas yang lebih tinggi daripada VCO yang melalui pemurnian dengan adsorben zeolit. Dengan adanya perlakuan pemurnian VCO dengan disaring menggunakan adsorben zeolit terbukti dapat menurunkan kadar asam lemak bebas VCO secara signifikan. Seperti pada kadar air, adanya penyaringan VCO dengan menggunakan adsorben zeolit terbukti berhasil menjerap sejumlah asam lemak bebas, sehingga kadar asam lemak bebas dalam VCO berkurang secara signifikan dan kualitas VCO menjadi lebih baik. Hasil analisis uji beda rerata dengan BNT (Tabel 3) pun menunjukkan bahwa terdapat signifikansi perbedaan rerata kadar asam lemak bebas menurut adsorben. Rerata yang berbeda secara signifikan terlihat dari nilai peluang $\mathrm{p}<0,05$, dimana antara kontrol dengan adsorben zeolit, semuanya memenuhi nilai peluang $\mathrm{p}<0,05$. Hal ini menunjukkan bahwa secara uji statistika terdapat perbedaan yang signifikan untuk perlakuan pemurnian dengan adsorben dan kontrol terhadap kadar asam lemak bebas dalam VCO.

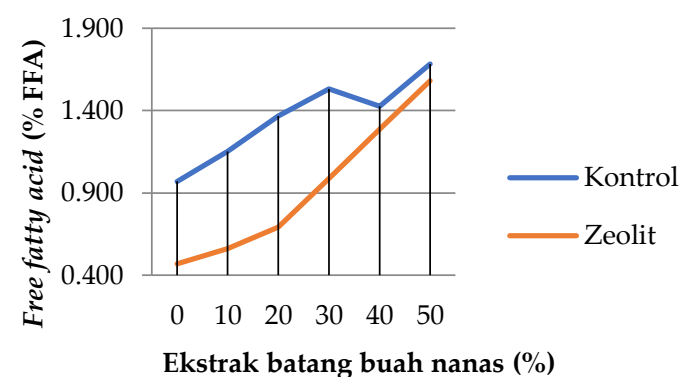

Gambar 3. Perbandingan kadar asam lemak bebas VCO kontrol (tanpa pemurnian dengan adsorben zeolit) dengan kadar asam lemak bebas VCO (melalui pemurnian dengan adsorben zeolit)

Tabel 3. Hasil uji beda rerata dengan BNT pada perlakuan pemurnian dengan adsorben terhadap kadar asam lemak bebas

\begin{tabular}{cccc}
\hline (I) Adsorben & $\begin{array}{c}\text { (J) } \\
\text { Adsorben }\end{array}$ & $\begin{array}{c}\text { Perbedaan } \\
\text { rerata (I-J) }\end{array}$ & $\begin{array}{c}\text { Signifikansi } \\
\text { (p) }\end{array}$ \\
\hline $\begin{array}{c}\text { Tanpa } \\
\text { pemurnian } \\
\text { (Kontrol) }\end{array}$ & $\begin{array}{c}\text { Adsorben } \\
\text { zeolit }\end{array}$ & 0.427 & 0.000 \\
\hline
\end{tabular}

\section{Kesimpulan}

Dari penelitian ini dapat diperoleh kesimpulan bahwa produksi VCO secara enzimatis dengan penambahan ekstrak batang buah nanas yang mengandung enzim bromelin terbukti dapat meningkatkan rendemen VCO, dengan konsentrasi ekstrak batang buah nanas untuk menghasilkan produk VCO dengan 
rendemen maksimal adalah pada konsentrasi $20 \%$. Pemurnian VCO dengan adsorben zeolit dapat menurunkan kadar air dan kadar asam lemak bebas secara signifikan, sehingga kualitas VCO menjadi lebih baik.

\section{Daftar Pustaka}

1. Babu, A. S.; Veluswamy, S. K.; Arena, R.; Guazzi, M.; Lavie, C. J., Virgin coconut oil and its potential cardioprotective effects. Postgraduate medicine 2014, 126, (7), 76-83.

2. Iranloye, B.; Oludare, G.; Olubiyi, M., Antidiabetic and antioxidant effects of virgin coconut oil in alloxan induced diabetic male Sprague Dawley rats. Journal of Diabetes Mellitus 2013, 3, (04), 221.

3. Nevin, K.; Rajamohan, T., Effect of topical application of virgin coconut oil on skin components and antioxidant status during dermal wound healing in young rats. Skin Pharmacology and Physiology 2010, 23, (6), 290-297.

4. Whitaker, J. R., Principles of enzymology for the food sciences. CRC Press: 1993; Vol. 61.

5. Bhattacharyya, B. K., Bromelain: an overview. Natural Product Radiance 2008, 7, (4), 359-363.

6. Yusoff, M. F. B.; DS, K. R., Proses penghasilan bromelin daripada batang nenas. Pertanika 1990.

7. Nuraini, I.; HP, D. S. H.; Hardyanti, I. S.; Wibowo, E. A. P. In Analisis Keefektivan Zeolit pada Proses Adsorbsi Pemurnian Minyak Jelantah, Prosiding Seminar Nasional ReTII, 2017.

8. Sudarmadji, S.; Suhardi; Haryono, B., Analisa bahan makanan dan pertanian. Liberty Yogyakarta: 1989. 